\title{
Third Congress of Physiological Sciences of Serbia with international participation (October 29-31, 2014, Belgrade, Serbia) (Report)
}

The Third Congress of Physiological Sciences of Serbia with international participation was held at the Military Medical Academy in Belgrade in period October 29-31, 2014. The Congress was organized by the Serbian Physiological Society, the Military Medical Academy and the Faculty of Medical Sciences, University of Kragujevac. The Congress was announced and held under the auspices of the Federation of European Physiological Societies (FEPS), the International Union of Physiological Sciences (IUPS), the International Society for Pathophysiology (ISP), and the International Academy of Cardiovascular Sciences. The congress was accredited for continuous medical education by the Health Council of Serbia as the highest-ranked international meeting. The Congress was also supported by the Ministry of Education, Science and Technological Development of Republic of Serbia as well by a few domestic and foreign sponsors. Co-Presidents of the Congress Program and Organization Committee were Dragan M. Djuric, Institute of Medical Physiology "Richard Burian", Faculty of Medicine, University of Belgrade, and Vladimir LJ. Jakovljević, Department of Physiology, Faculty of Medical Sciences, University of Kragujevac. The participants were welcomed by Marijan Novaković, Head of the Military Medical Academy, Vladimir Lj. Jakovljević, President of the Serbian Physiological Society and Vice-Dean at the Faculty of Medical Sciences, University of Kragujevac, Vladimir Štrbak, Institute of Experimental Endocrinology of the Slovak Academy of Sciences and Institute of Normal and Pathological Physiology of the Slovak Medical University, Bratislava, Slovak Republic, on behalf of the international physiological community, and Dragan M. Djuric, on behalf of the Congress Program and Organization Committee. This was followed by the presentation of biography and distinguished researcher award of the Serbian Physiological Society to Grant N. Pierce, College of Medicine, Faculty of Health Sciences, Department of Physiology and Pathophysiology, University of Manitoba and St. Boniface Hospital Research, Winnipeg, Canada, for his lifetime contribution in development of physiological sciences. Award was also assigned to Veljko Todorović, former Head of the Military Health Department at the Ministry of Defense of Republic of Serbia for his contribution to restoration and development of the Serbian Physiological Society.

A collection of abstracts presented at the Congress were published in English, cataloged at the Serbian National Library, and edited by Dragan M. Djuric and Vladimir Lj. Jakovljević. The Abstract book was included 196 accepted abstracts (selected by the Program Committee) from 27 countries (Belarus, Bosnia and Herzegovina, Bulgaria, Canada, Czech Republic, China, Cuba, France, FYR Macedonia, Germany, Greece, Hungary, Italy, Malaysia, Montenegro, Netherlands, Poland, Romania, Russia, Singapore, Slovenia, Slovakia, Sweden, Turkey, Great Britain, the USA and Serbia). Out of total number of papers, 63 were presented orally (plus 4 abstracts were published but were not presented on reasonable excuse), while 
129 papers were presented in poster sessions. Seventy percent of total number of abstracts was in the field of experimental (basic) research. The best poster was awarded at the Congress, and done by a group of young researcher from the Faculty of Medicine, Timisoara, Romania. Out of total number of presentations, 38 abstracts were accepted from abroad, and presented by 35 foreign participants. The Congress included the following sessions: progress in cardiovascular research, physiology and pharmacology of the heart, immunology and experimental oncology, progress of education in the domain of medical physiology together with new textbooks written in Serbian language at various universities in Serbia, physiology of various organs and oxidative stress, pharmacology and toxicology, endocrinology, neurobiology, neurophysiology, free topics, and innovative workshop on possibilities of application of telemetry in experimental animals. Two hundred and fifty researchers from the country and abroad participated in the Congress. In addition to participants, executive director and regional directors for Europe and North America of the International Academy of Cardiovascular Sciences, the head of the COST action BM 1005 of the European Scientific Foundation, the members of academies of sciences from Russia, Belarus and Canada, presidents of national physiological societies from Slovakia, Czech Republic and forthcoming president of the German Atherosclerosis Society, editors of international journals Canadian Journal of Physiology and Pharmacology, Molecular and Cellular Biochemistry, General Physiology and Biophysics were present at the Congress. In accordance with the tradition, a number of reviewed papers from the Congress as well as the report will be published in Acta Physiologica Hungarica, the scientific journal of the Hungarian Academy of Sciences.

It should be noted that social program was interesting and that the participants, as they said, had nice memories of bohemian quarter Skadarlija, winery Vrbica near town Aranđelovac, restaurant Kalemegdan terrace, Ada Ciganlija lake, visit to regional basketball derby and specially organized tennis games with the legends of Serbian physiology, and unforgettably enjoyed delicious Serbian cuisine and international music.

Judging by the number of abstracts in basic medical research, the number of foreign participants and the scientific quality of presentations, this Congress was probably the most successful one in the domain of biomedical sciences in Serbia in the last few years.

Professor Dr Dragan M. Djuric

President, Program Committee 